\title{
Children, mothers, and preschool teachers' perceptions of play: Findings from Turkey and Norway
}

\author{
Çocukların, annelerin ve okul öncesi öğretmenlerinin oyun algıları: \\ Türkiye ve Norveç bulguları
}

\author{
Asiye İvrendi ${ }^{1}$, Nilgün Cevher-Kalburan ${ }^{2}$, Ellen Beate Hansen Sandseter ${ }^{3}$, Rune Storli ${ }^{4}$, Anne \\ Holla Sivertsen $^{5}$
}

\begin{abstract}
Article History
Received : 21 November 2018

Revised : 27 December 2018

Accepted : 23 January 2019

Online : 25 January 2019
\end{abstract}

\section{Article Type}

Research Article

\begin{abstract}
This cross-cultural study aims to explore children's, mothers', and teachers' current perceptions of play in Turkish and Norwegian cultures by using the Cultural Historical Action Theory framework as an analytical tool. The participants included 40 children enrolled in preschools, 39 mothers, and 10 teachers. In this cross cultural comparative study, structured interviews were used to collect the data. The results revealed one common theme across the participants' definitions of play, the feelings related to play. All three groups expressed play as a way of having fun. Another common theme for the adults from both countries were the ideas that, play is important for children's learning and development and, it is impossible to think of an alternative to play. Both Norwegian and Turkish children defined play as different examples, such as cars, bicycles and balls. While Norwegian teachers defined play as a context in which children make their own decisions, both Norwegian and Turkish teachers considered play socialize with friends and to be a way of communication. The concept of adults as the community of play and children as the actors of play deserve more attention
\end{abstract}

Keywords: International play; Play definitions; Play preferences.

Öz: Bu kültürler arası çalışma, çocukların, annelerin ve öğretmenlerin Türk ve Norveç kültürlerindeki mevcut oyun algılamalarını, analitik araç olarak Kültürel Tarihsel Aktivite Kuramı çerçevesini kullanarak incelemeyi amaçlamaktadır. Katılımcılar anaokuluna kayıtlı 40 çocuk, 39 anne ve 10 ögretmenden oluşmaktadır. Sonuçlar, katılımcıların oyun tanımları arasında oyunla ilgili duyguların ortak bir tema olduğunu ortaya koymuştur. Her iki ülkeden yetişkinler için başka bir ortak temanın, oyunun çocukların öğrenme ve gelişmesi için önemli olduğu ve oyuna bir alternatif düşünmenin olanaksız olduğu belirlenmiştir. Hem Norveçli hem de Türk çocuklarının oyunu farklı örnekler kullanarak görülmüștür. Ayrıca, Norveçli öğretmenler oyunu, çocukların kendi kararlarını aldıkları ve arkadaşlarıyla sosyalleștikleri bir bağlam olarak tanımlarken, Türk öğretmenler oyunun bir iletişim yolu olduğunu düşünmektedir. Araştırmada elde edilen bulgular 1şığında Kültürel Tarihsel Aktivite Kuramına göre oyunun sosyal çevresini oluşturan yetişkinlerin ve oyunun aktörleri olan çocukların oyun algılarının daha derinlemesine araştırılmasının önemi vurgulanmıştır.

Anahtar Kelimeler: Uluslararası oyun; Oyun tanımları; Oyun tercihleri.

DOI: $10.24130 /$ eccd-jecs.1967201931119

\footnotetext{
Corresponding Author: Nilgün Cevher-Kalburan

1 Pamukkale University, Educational Faculty, Early Childhood Education Department, Denizli, Turkey, e-mail:aivrendi@pau.edu.tr, ORCID: http://orcid.org/0000-0002-0555-9247

2 Pamukkale University, Educational Faculty, Early Childhood Education Department, Denizli, Turkey, e-mail:nkalburan@gmail.com, ORCID: http://orcid.org/0000-0003-0622-1480

3 Queen Maud University College of Early Childhood Education, Trondheim, Norway, e-mail: ebs@dmmh.no, ORCID: http://orcid.org/00000002-3315-6955

${ }^{4}$ Queen Maud University College of Early Childhood Education, Trondheim, Norway, e-mail: rus@dmmh.no

${ }_{5}^{5}$ Queen Maud University College of Early Childhood Education, Trondheim, Norway, e-mail: ahs@dmmh.no, ORCID: http://orcid.org/00000002-0861-1012
}

\footnotetext{
Atıf için/To cite this article:

İvrendi, A., Cevher-Kalburan, N., Hansen Sandseter, E., Storli, R., \& Holla Sivertsen, A. (2019). Children, mothers, and preschool teachers' perceptions of play: Findings from Turkey and Norway. Erken Cocukluk Calışmalar Dergisi, 3(1), 32-54.
}

DOI:http://dx.doi.org/10.24130/eccd-jecs.1967201931119 


\section{INTRODUCTION}

No matter where children live, children play; perhaps in different forms and with different materials, but children all over the world step in and out of the world of play. As essential as it is, due to its spontaneity and unpredictability, play is a complicated childhood experience to define (Whitebread, Coltman, Jameson \& Lander, 2009). This complexity may stem partly from how the stakeholders--children, mothers and teachers--perceive play and from how early childhood literature approaches the world of children's play. This study takes this complexity into account by using the cultural historical activity theory framework as an analytical tool.

Research studies examining children's perceptions of play provided evidence as to their thoughts about play's distinguishable features (Howard, 2002; Karrby, 1989; Oers, 2013; Wing, 1995), play types (Einarsdottir, 2014; Vickerius \& Sandberg, 2006), play related feelings, materials, and interactions (Koçyiğit \& Baydilek, 2015; Ramazan, Özdemir \& Beceren, 2012). For example, Vickerius and Sandberg $(2006,212)$ determined that children's definitions were comprised of examples of different kinds of play, for instance, family play. Einarsdottir (2014) concluded that children define play by such characteristics as self-initiation, freedom of choice, fun, opportunities for creativity, and being with friends without the presence of adults' influence and control. A recent study by Pyle and Alaca (2018) informed that the play environment and teacher's presence during play are determining factors of children's perception of play. This study showed that in classrooms where children mostly engage in free play and teachers were absent from play, children did not connect play with learning. Contrary, in classrooms where children engage in varied types of play and teachers were active participants of play, children connected play with learning. In conclusion, children's play definitions focused on play types and play related feelings as well as adult's absence in play process.

What adults like parents and teachers think about play is essential since their perception may impede or facilitate play opportunities. Studies related to parents' play perceptions show that parents view play as a means of having fun (Rothlein \& Brett 1987; Vickerius \& Sandberg, 2006) and supporting children's development (Erbay \& Saltalı, 2012). Research conducted in different cultures showed that parents value play and consider it as important for child development (Shiakou \& Belsky, 2012; Temur \& İnan, 2010). In contrast, some parents do not consider play to be an appropriate way for children to learn (Badzis, 2003). McInnes, Howard, Miles, and Crowley (2011) investigated preschool teachers' definition of play. Findings showed that teachers who did not have a clear understanding of play and their role in children's play had a tendency to engage in 
adult-led activities more than child-led activities. This finding implies that teachers with a wellgrounded understanding of play aware of the value of play for children's learning and hence facilitate child-led activities.

The context in Turkey: According to 2015 statistics data, Turkey's population is about 79 million. The child population is almost 23 million. The percentage of women (15+ years old) who work is 29.2 $\%$ (Turkish National Education Statistics, 2017). Children can be enrolled in preschools at the age of 36 to 66 months, it is not mandatory. In the 2016-17 academic year, 53.01\% of four to five years-old children were enrolled in preschools (Turkish National Education Statistics, 2017). Parents can choose between private, semi-independent public, and public preschools. Private preschools have a monthly fee.

The context in Norway: According to 2016 statistics, Norway's population is about 5.25 million. The population of children between 0-17 years is 1.1 million. The percentage of women (15+ years old) who work is $65 \%$ (Statistics Norway, 2017). Children can be enrolled in preschools at the age of 10 to 68 months, and it is not mandatory. Parents can choose between private and public preschools and both have the same monthly fee. In 2016, a total of 283000 (91\%) of the children between the age of one and five attended to preschool education.

\section{Play in Turkish Culture}

Just as in many cultures, children's play has an important place in Turkish culture. From the past, children's play has been extensively researched in terms of children's development and learning (Özdemir \& Ramazan, 2014; Tekin \& Tekin, 2007). With the UN Children's Rights Convention Article 31, play is recognized as one of rights of children. After that, studies on the preparation and implementation of programs in national educational institutions according to play-based learning principles have become even more pervasive. However, research conducted in Turkey show that physical features of the playgrounds and professional qualifications of the teachers do not sufficiently afford children to benefit from the developmental efficacies of the play (Küçükali, 2015). With regard to the place of play in preschool education, the national curriculum, which is based on constructivist learning principals, emphasizes play as the core feature. The curriculum states that the children should have approximately an hour of free play each day and teacherdirected play time (Turkish Ministry of National Education, 2013). In addition, the common higher education program of early childhood education has mandatory courses titled "children's play and physical activities", "play development" as well as elective courses. 
The growing literature on Turkish parents' view about play show prominent results regarding their positive thoughts about play and participation in play. More precisely, parents with higher education and income level appear to have supportive views about the role of play in children's development and engage in their children's play (Isıkoglu \& Ivrendi, 2008; Ivrendi \& Isıkoglu, 2010). In another study, it was discovered that Turkish mothers had less awareness of what play was and what play was not, while they believed play was important for motor and cognitive development of children (Temur \& Inan, 2010). Oksal's study (2005) showed that Turkish mothers' had less awareness of play so that they played a role as directive and manipulator during children's play.

Studies conducted with Turkish children reveal enjoyment as a feature of play (Koçyiğit \& Baydilek, 2015; Ramazan et al, 2012). A study found children's criteria for defining an activity as play included toys, having fun, and having been planned by children (Koçyiğit \& Baydilek, 2015). A broad study by Erdoğan, Haktanır, Akyol, and Ilhan (2004) revealed that six years-old children wished to play in outdoors, with friends and with their family members. This study also emphasized the importance of outdoor play in children's lives and drew attention to the need to include more outdoor play opportunities in the educational curriculums.

Research related to preschool teachers' play perception revealed that teachers defined play by stating its characteristics and effects on development and learning (Özdemir \& Ramazan, 2014; Tekin \& Tekin, 2007). Turkish preschool teachers defined play with its several characteristics. Among these were play has an effect on development and learning, helps children to realize their potential, foster joy (Özdemir \& Ramazan, 2014), and presents opportunities for creativity, socialization, and positive feelings (Tekin \& Tekin, 2007; Tuğrul, 2017).

\section{Play in Norwegian Culture}

In Norway, the children's right to play is regarded as an important element of preschool content and is closely related to the children's right to participate, to be responsible, and to be active (the rights of children enshrined in Article 12 of the UN Convention on the Right of the Child). Play is considered to have an intrinsic value and to be a part of child culture: According to Article 12, "Play shall be a key focus in kindergarten, and the inherent value of play shall be acknowledged. Kindergartens shall make good provision for play, friendship, and the children's own culture." (Norway Ministry of Education and Research [NMER] 2017, 20). Play is thus regarded as a means for learning and developing a complex set of skills, and this means that preschool professionals have special obligations to ensure and support children's play. 
While children's free play indoors is important in the Norwegian context, outdoor play is particularly emphasized in the Framework Plan: "Kindergartens shall enable the children to appreciate nature and have outdoor experiences that teach them to move around and spend time in the outdoors during the different seasons" (NMER 2017, 52). Because of this, staffs in kindergartens are obliged to look at the physical framework for children's play and learning environments as an entity. Children attending Norwegian preschools usually spend a great amount of time outdoors, more than $70 \%$ of the total time in preschool in the summer term and more than $30 \%$ of the total time in the winter term (Moser \& Martinsen 2010, 20). A study that aimed to capture children's perspectives on their everyday lives (both indoors and outdoors) in Norwegian preschools, their experiences of well-being, and the opportunity for participation found that there was a significantly $(\mathrm{p}<.001)$ higher level of opportunity for children to decide for themselves what to do outdoors than indoors (Bratterud, Sandseter \& Seland, 2012; Sandseter, 2012).

\section{Play within a CHAT Framework}

Göncü and Gaskins (2007) stated that because play is a complex phenomenon, the integration of its multiple perspectives has been difficult. However, exploring differences among understandings of play may offer an insight into efforts that enrich play opportunities, gear up play provisions, and thereby enforce the place of play in settings for children. The majority of research has examined play from the viewpoints of adults. There is very little research that has examined children's, parents', and teachers' understandings of play together (McInnes \& Birdsey, 2015; Rothlein \& Brett, 1987), and, to the best of our knowledge, there is no research about it in Turkey or Norway. One way to investigate perceptions of play by different stakeholders is to situate play in the culturalhistorical activity theory (CHAT). CHAT has been found to be effective for examining events, situations, and tasks by considering their relevant context (Nussbaumer, 2012, 37).

CHAT views play "as a way an activity is carried out" (Oers, 2013, 190) and has six components: a subject, an object, the tool(s), the community, the rules, and the division of labor. The subject is the actor of the activity. The object is the goals or purpose (Foot 2014; Sundberg, Areljung, Due, Ekström et. al, 2016). The tool(s) refers to a variety of instruments like language and materials. The community consists of individuals who share the same goals as the subject. The "rules" in an activity predicates the subject's actions and interactions toward the purpose of the activity. The division of labor means splitting up tasks, power, and positions. The components of rules and the division of labor facilitate the relations between the subject and the community (Foot, 2014). The rules, community, and division of labor bring up the socio-historical features of mediated action 
(Yagamata-Lynch, 2010). CHAT considers tools as "crafted at a point in time and adapted over time. Their development is shaped by the needs, values, and norms of the culture(s) in which they are created and used" (Foot, 2014, 331).

In play, children can be considered as the subject. The object is the purpose of play. The language, materials, or toys used in play make up the tools which are influenced by the play needs, values, and norms of the specific culture. Children, parents, and teachers constitute the community. In the context of play, a variety of rules may exist, such as determining where to play, with what, with whom, and when. The division of labor in play may indicate who is making the decisions about play related issues, such as play type, area, and materials.

While it is cultural norms, values and needs that determine play tools, the rules and division of labor influence the relations between the children and significant others in play (Foot, 2014, 331). For example, the cultural values support parents' participation in play and children making their own play decisions. Adults' beliefs about children's development and their communities' social structure influence children's play (Göncü, Mistry \& Mosier, 2000). This influence show itself in the form of what is made available for children; such as the types of play opportunities, materials, and programs that adults provide (Morris, 2013). Additionally, beliefs about play and the value it is given in a culture influence the process of play including "the amount of play, customs reflected in play, gender roles associated with play, and objects considered appropriate for play" (Frost, Wortham \& Reifel, 2001, 285). Hence, exploring play by using the components of the CHAT framework in different cultures may contribute to efforts to better understand the influence of cultures on child play.

\section{Aim of Study}

The aim of this study is to explore children's, mothers' and teachers' current perceptions of play in Turkish and Norwegian cultures by using the CHAT framework as an analytical tool. Moreover, CHAT serves to unpack areas of similarities and differences between play perceptions of participants from these two cultures. We focused on three research questions:

(1) How do play definitions of children, mothers and teachers differ in the two cultures?

(2) What alternatives to play were expressed by children, mothers and teachers in the two cultures?

(3) How do play preferences (materials, places, play-mates) of children, mothers and teachers differ in the two cultures? 


\section{METHOD}

This research was designed to investigate the play understandings of children, mothers, and teachers from two different cultures. Therefore, a cross cultural comparative study was used. The research team decided on a qualitative approach to collecting the data. This was done because we, as a part of the study, were searching for children's own perceptions of play as a phenomenon, and their experiences and feelings connected to play, and personal and qualitative interviews would be a suitable method for of obtaining children's experiences and perceptions on a certain phenomenon (Graue \& Walsh, 1998; Greig et. al., 2007). Similarly, a qualitative interview with the mothers and teachers would give us in-depth information about their perception of play as a phenomenon and their experiences of the children's play, as well as the opportunity to follow up their answers with additional and clarifying questions. As such, we position this study with a phenomenological approach where we search for the interviewees lived and emotional experience of play (Van Manen, 1997).

\section{Participants and Settings}

The participants were children, mothers, and preschool teachers. A specific procedure was followed to select the participants. The researchers randomly selected five preschools and five volunteered teachers from each preschool in each country. Then, each teacher chose two boys and two girls from her classroom. The children's mothers' permission was obtained. From each country, there were 20 children, 20 mothers, and 5 teachers; 40 children, 39 mothers and 10 teachers in total. One of the Norwegian mothers withdrew from the study; thus, a total of 19 Norwegian mothers were interviewed.

In the Turkish sample, three of the schools were public pre-schools, and two of them were public schools. In the Norwegian sample, three of the ECEC institutions were public, and two were private. The majority of the Turkish children were five years old. The majority of mothers had an education level below college, and more than half of them had two or more children. The mean age of the mothers was $32.90(\mathrm{SD}=5.31)$ while the mean age of the teachers was $35.80(\mathrm{SD}=4.43)$. The mean years of teaching experience was $12(\mathrm{SD}=5.24)$.

The majority of Norwegian children were five years old. All of the children had been enrolled in preschool since the age of one. Almost all of the mothers had a college degree at the bachelor, master or PhD level. One of the mothers had a certificate of apprenticeship. The mean age of the mothers was $37.47(\mathrm{SD}=3.19)$, while the mean age of the teachers was $39(\mathrm{SD}=8.51)$. The mean 
years of teaching experience was $15.1(\mathrm{SD}=7.6)$.

\section{Data Collection Procedures}

Data collection was carried out in the academic year of 2015-2016, and it lasted approximately two months. Structured interview questions were used to collect data from the children, mothers and teachers. Interview guides were developed for each of the interview groups of children, mothers and teachers. The interview guides included items to code demographic information, instruction for the interviewer, questions to be asked and closing statement. After developing the first version of the interview guide, a pilot study was conducted with three teachers, 20 children, and their mothers to examine the comprehensibility of the interview questions. Based on the pilot study, the data collection procedure and the items were revised and finalized to enable similar data collections in both countries.

Each participant was individually interviewed. The Turkish children's responses were audio-taped while the mothers' and teachers' responses were written using paper and pencil with practical grounds. In Norway, all the responses from children, mothers, and teachers were audio-taped. In both countries, the data obtained from the interviews was transcribed. The children were interviewed by using a game format. A toy microphone was used, and the interviewer made the following explanation to the children: "We will play a game with you. In this game I am a reporter. I will talk with you by using this microphone. I will hold the microphone, and when I hold it towards you I want you to answer my question. If you want, after I finished my questions, you can be a reporter and ask me questions. Are you ready?" Following this explanation, the questions were asked (See Appendix 1).

The Turkish data was collected by one pre-service preschool teacher candidate. She was trained in the process of conducting interviews with children and adults. To ensure reliability, the trained student conducted a pilot interview with children and adults. After that the researchers examined the interviewed process and feedback to the trained student. The Norwegian data collection was conducted by a professor, an associate professor, and an assistant professor, all of them researchers at an early childhood university college.

The Turkish participants were interviewed in a suitable room at the preschools. It was optional for the children to have a teacher with them during the interview. In Norway, the interviews with mothers were conducted at any place they suggested (at home, at a cafe, at the preschool, etc.). The length of interviews was approximately 10 to 15 minutes for both countries. 
The interview questions were meant to allow participants to describe their unique experiences and express the meanings of play. Subsequent to the questions, a total of 22 photographs of play materials and places were shown to the participants to determine the ones that the child wants and was able to play with; and ones that the child and wants but is not able to play with. As an example, the parents were asked the following questions respectively "Which one of these your child likes to play most?", "Why do you think your child likes to play with the one that just you chose? Please explain.", "Which one of these your child likes to play but he/she cannot play?", "Why do you think your child cannot play with the one that just you chose? Please explain.” During the interview, the reverse side of the photos were put on the table until the relevant questions were asked. With regard to the questions related to photographs of play materials and places, the participants' preferences and their reasons for those preferences were recorded on a checklist.

\section{Ethical Considerations}

After obtaining permission from the Provincial Directorate for National Education, the researchers communicated with the principals and teachers of the preschools about the purpose of the study. Before the interviews took place, informed consent was obtained from the preschool teachers and the parent of each child (so that they could be a part of the study themselves, but also so that their children could be involved) as well as written informed consent from each child. All the participants could withdraw from the study at any time.

\section{Data Analysis}

Researchers from each country analysed the data separately. In order to understand the data thoroughly, the raw data from the children's, mothers', and teachers' interviews were read in depth and then analysed separately by the researchers. Each group of participants' data was analysed separately. In both countries data were analysed using a thematic analysis technique (Patton, 2015; Grbich, 2013) where the thematic content of the interviewees' expressions and perceptions was coded and classified in direct relation to each of the research questions. In Turkey, all of the data were manually analysed. In Norway, all of the data was transcribed and coded in the analysis software NVivo (QSR International). The thematic content analysis of the Norwegian data was therefore conducted in NVivo (QSR International). In both countries, in doing the content analysis, first, the repeatedly occurring significant statements were coded. Then, the related statements were thoroughly examined and classified and, ultimately, common themes were identified (Creswell, 1998). The Turkish child participants who were interviewed were named TC1, TC2...TC20; the mothers were named TM1, TM2...TM20; and the teachers were named TT1, 
TT2...TT5. The Norwegian child participants were named NC1, NC2...NC20; the mothers were named NM1, NM2...NM19; and the teachers were named NT1, NT2...NT5.

\section{RESULTS}

By examining children's, mothers', and teachers' responses to the questions and the differences in and similarities to their current understandings and definition of play were identified and results presented in Table 1.

Table 1. Play definitions by country

\begin{tabular}{|c|c|c|}
\hline & Turkey & Norway \\
\hline $\begin{array}{l}\text { Children's play } \\
\text { definitions }\end{array}$ & $\begin{array}{l}\text { - Examples of play, toys, and play place } \\
\text { - Feelings: play as a way of having fun } \\
\text { - Action } \\
\text { - Social: being with friends }\end{array}$ & $\begin{array}{l}\text { - Examples of play and toys } \\
\text { - Feelings: play as a way of having fun } \\
\text { - Social: being with friends } \\
\text { - Being in a role: like in a family or as an } \\
\text { animal }\end{array}$ \\
\hline $\begin{array}{l}\text { Mothers' play } \\
\text { definitions }\end{array}$ & $\begin{array}{l}\text { - Examples of play, toys, and play place } \\
\text { - Feelings: play as a way of having fun } \\
\text { - Action } \\
\text { - Effect of play on development and } \\
\text { learning } \\
\text { - Play as a way of spending time and energy } \\
\text { - Play as a way of communication }\end{array}$ & $\begin{array}{l}\text { - Social: being with friends } \\
\text { - Feelings: freedom, fun and excitement. } \\
\text { - Fantasy world: their own imaginary world } \\
\text { - Effect of play on development and learning: } \\
\text { language and social codes. } \\
\text { - Play as a way of using their bodies } \\
\text { - Play as a way of deciding on their own } \\
\text { - Play as a way of communication }\end{array}$ \\
\hline $\begin{array}{l}\text { Teachers' play } \\
\text { definitions }\end{array}$ & $\begin{array}{l}\text { - Feelings: Play as a way of having fun } \\
\text { - Effect of play on development and } \\
\text { learning } \\
\text { - Play as a way of communication }\end{array}$ & $\begin{array}{l}\text { - Feelings: fun, freedom and excitement } \\
\text { - Effect of play on development and learning } \\
\text { - Children deciding for themselves } \\
\text { - Social: being with friends }\end{array}$ \\
\hline
\end{tabular}

As seen in Table 1, there were similarities and differences among children, mothers and teachers' play definitions between the countries. A common theme in both the Turkish and Norwegian participants' definitions of play was "Feelings: play as a way of having fun." A mother expressed her views as follows:

“Children are unhappy when they don't play. When a child wants to play with her mother, and she is rejected, she feels disappointed. So, play is a thing that makes children very happy." (TM3)

One of the children stated: "Play is just having fun. So it's just fun, fun and fun." (NC2)

Turkish children defined play as action and socializing with friends while Norwegian children defined it as being with friends and taking roles. Turkish children stated that "Play is to play." Some 
children expanded this statement either by adding the social aspect or the material aspect to it by stating "Play is to play with friends", "Play means friends and toys", and "Play is to play with toys."

According to a Norwegian teacher; "You cooperate with others, and, by having a conversation, you can manage to expand what you are doing. You are talking together." (NT5)

"I think about a fantasy world, totally giving in to it and taking other roles." (NM5)

One of the children expressed it this way: "Play means getting a new friend. If someone asks you to play with them, you have a friend." (NC1)

A common theme among the mothers and teachers across the cultures was about the benefits of play like developing social and communication competence. TT2 explained her thoughts regarding play as a way of self-expression as follows:

"Play is children's occupation, in fact. A child expresses herself, and she is totally natural during play. She learns everything and shares her observations while playing. In play, she displays what she observes around her."

“Children see it (play) as work. Just as our work is never done, children's play never finishes, too. When you call them, they say 'it has not finished yet.' When they are playing, my children always say 'I have lots of work."” (TM1)

"You cooperate with others, and by having a conversation you can manage to expand what you are doing. You are talking together." (NT5)

There was also a difference between the mothers from the two countries. While some of Turkish mothers considered play as a way of spending time and energy, some of Norwegian mothers perceived it as a way of using their body and as a way of children making their own decisions as seen in their comments below.

"Play is discharging and having a good time in the sense of children. Because, there is no a specific 'time zone' to children's way of thinking. Their energy is so high!" "Discharging their energy is something really important when it comes to play" (TM2).

"Play is self-determined, you choose it yourself. You choose what you do." (NT4)

"Play is self-determined, you choose it yourself."(NT5) 
"They [children] get absorbed in play, and they don't care about what is going on in the surroundings. Totally concentrated.” (NM3)

For Turkish mothers, play was a vehicle to spend time. They emphasized spending time with others and/ with fun. Both Norwegian mothers and teachers emphasize the feeling of freedom and concentration in play. Children's special focuses in play were also mentioned by one of the mothers.

Taken together, the results show that children and adults differ in terms of how they see and argue for the value of play. Mothers and teachers seem to describe play through its learning function, its utility value/usefulness, while this was certainly not a focus for the children who describe play by its own value (here and now experience).

\section{Results of Participants' Comments about Alternatives to Play}

In comparing participants' responses to alternatives to play, only teachers and mothers' responses were taken into account since there were too much missing child data about this question. Results related to this question are presented in Table 2.

Table 2. Alternatives to play by country

\begin{tabular}{|c|c|c|}
\hline & Turkey & Norway \\
\hline $\begin{array}{l}\text { Mothers' } \\
\text { alternatives }\end{array}$ & $\begin{array}{l}\text { - Impossible } \\
\text { - It would be boring } \\
\text { - Children could not learn and develop } \\
\text { - Life would be hard } \\
\text { - Adults would have to entertain children } \\
\text { - There would be technological devices as an } \\
\text { alternative of play } \\
\text { (tablet/computer/internet/television) }\end{array}$ & $\begin{array}{l}\text { - Can't imagine it } \\
\text { - Children would be working or at school } \\
\text { - Children could not learn and develop } \\
\text { - They would be sad and apathetic } \\
\text { - The fantasy would disappear } \\
\text { - They would do something else } \\
\text { - They would become violent }\end{array}$ \\
\hline $\begin{array}{l}\text { Teachers' } \\
\text { alternatives }\end{array}$ & $\begin{array}{l}\text { - Impossible } \\
\text { - It would be boring } \\
\text { - Children could not learn and develop }\end{array}$ & $\begin{array}{l}\text { - Impossible } \\
\text { - They would still play } \\
\text { - They would be working or at school }\end{array}$ \\
\hline
\end{tabular}

A couple of similarities and differences between mothers and teachers' thoughts about the alternatives to play emerged across countries. A common response from all participants was the impossibility of having an alternative to child play. In other words, the participants couldn't imagine a world without play. Besides, Turkish mothers, teachers and Norwegian mothers, but not the teachers addressed children's development and learning when they expressed their thoughts about the alternatives of play.

"Certainly, they play anyhow. Then, I do not know, what would be its name, but they would play 
anyhow. This is something comes from inside. I mean, children have to play! They cannot resist this. What would be if there is no play? I cannot think about something like that!” (TT3).

"It is impossible to imagine." (NT3).

“They would still play.” (NT4).

Moreover, whilst all Turkish participants saw the world as boring without play, Norwegian mothers and teachers replaced play with working or being at school. As another alternative to play, Turkish mothers thought technological devices, while Norwegian mothers focused on feelings like being sad and apathetic, and mentioned violence and losing fantasy in the absence of play.

Instead of play, someone would have to tell the children what to do, they would be more at school and the children would lose their body language. Additionally, the mothers talked about children's feeling if there was no play. A majority of the mothers claimed that children would have an empty feeling and be more aggressive and violent. If there were no play, some of the mothers thought their children would be sad. Instead of play, children would have to work and copy the everyday life of adults.

"For example, when there is no play, a child takes a tablet or watches television. She spends time in this way. In my opinion, if we switch off the television, the child goes to play." (TM6)

"I think they would be doing more work related to everyday life" (NM2)

"I think children would be more introvert. They use their play for everything. No playing would influence their psychological health. They would not have a normal development." (NM6)

\section{Results of Play Preferences}

Results related to the question about play materials that children can and cannot play revealed some similarities and differences across the countries. According to the Turkish children and their mothers, the most popular play materials were Lego blocks. While "technological devices" and "puzzle" were selected only by some Turkish children and mothers, a few Turkish teachers' chose dramatic play and art materials. The reasons for those two choices were "being a girl" and "not letting the child go outside". Many Norwegian children said that they would prefer to play in a playground in a shopping mall. According to Norwegian mothers, their children would prefer to 
play in/with fixed play equipment, whereas several Norwegian teachers said the children would like to play with dramatic play materials. Norwegian mothers mentioned limited access to play materials and the ability of physical activity as some reasons of their choices. While Turkish children did not prefer playground in a shopping mall, street, and with sports equipment, Norwegian children did not choose educational toys, sand, music and art materials, water, nature, and street. In both countries, the most common reason was about feelings like having fun, being happy, and arousing children's interest.

Both Turkish and Norwegian participants chose technological devices as the materials that the children cannot play. Turkish participants' reason was parents do not give permission to use them for the child's wellbeing. Turkish teachers' reasons were that "because those kinds of tools (tablet and phone) are not available at school". In addition, both some Turkish and many Norwegian mothers thought there is no play material that children cannot play. As different from Turkish children's responses, some Norwegian children stated that they can play with whatever they want. In parallel, more Norwegian teachers than Turkish teachers stated that the children have freedom about playing. Whilst Norwegian teachers had an impression that children cannot play in a playground in a shopping mall, a few Turkish teachers said that children cannot play with sand and ball. Besides, "music materials" are among the least accessible materials for both countries' participants. Another notable finding is that while fixed equipment, such as slides and climbing ladders, is never mentioned by the Norwegian participants in terms of what children cannot play, there is limited access by the Turkish participants in all three groups. The reasons for this were mostly parents' limited time, distance of the playgrounds. In addition, the Turkish participants stated fear of being sick or getting injured as reasons while this was not a reason for the Norwegian participants. While many of the Norwegian teachers said "because child does not have [that play material])" as a reason of not playing, others showed having limited access as a reason. In parallel, many Turkish children and mothers gave "does not have that play material" as a reason for why children cannot play with certain play materials. Some Turkish children and mothers mentioned not having enough ability (e.g. jumping rope) while some teachers stated that they do not go outside (so children cannot play with balls, bicycles, water etc.).

\section{CONCLUSION and DISCUSSION}

This study provides a window into children, mothers and teachers' perception of play in Turkey and Norway. Moving from the CHAT framework, the subject in the play activity was the children, parents, and teachers since the main interest of this study was to explore definitions of play, 
alternatives to play, and play preferences based on the perceptions of these three groups of participants. There were commonalities and differences in the subjects' definitions of play.

Through the eyes of all subjects across the cultures, the object of play activity was feelings such as having fun and being happy. 'Feelings' as a purpose of play is not unique in itself. In fact, this finding of play as being fun coincides with other studies' findings (Özdemir \& Ramazan, 2014; Tekin \& Tekin, 2007; Vickerius \& Sandberg, 2006). Having said that, an intriguing aspect of this finding is that not only children but also adults across cultures perceive the issue of feelings as part of their play definitions. The context of play appears to entail positive feelings such as having fun and being happy.

Apart from this common object, Norwegian and Turkish children and mothers differed from the adult participants of Norwegian and Turkish teachers. For them, play definition entails tools of the play activity, that is examples about play and play related things, including toys and play places. The tools mentioned by the children were balls, blocks, sand, tablets, bicycles, tricycles, and skateboards. Play places, such as playgrounds, shopping malls and streets were also among the children's responses. The finding related to the children's defining play with examples concurs with Vickerius and Sandberg's (2006) findings indicating that children also used play examples when defining play. As Johnson, Christie, and Wardle (2005) stated, play is abstract, it has multiple meanings, and it is easier to exemplify; thus, children might use play examples which they have experienced concretely. Being with friends was another object stated only by the Norwegian and Turkish children. This object relates to the community component reflecting with whom they share the play activity. The social aspect of play seems to be more appealing for the children than the adults. Because children's perceptions are related to their experience (Howard et. al. 2002), Norwegian and Turkish children defined play as "playing with friends and/or toys" which is their own experience.

When examining common findings related to mothers and teachers' definitions of play, a common object was about what play actually does, such as its effect on development and learning and as a way of communication. These adults thought that children express themselves and communicate with others through play. Concurring with the results of other studies from Turkey (Erbay \& Saltal, 2012; Özdemir \& Ramazan, 2014; Tekin \& Tekin 2007), the parents and the teachers stated that play is important for children's learning and development. This finding is encouraging in that two of the important adults in children's lives relate play to children's development and learning. Teachers' understanding of play influences their practices. Recognizing the value of play in terms of children's wellbeing is essential but not enough, unless these understandings about play become 
part of adults' practices. Further research can be designed to investigate parents' and teachers' practice regarding play to reveal how they transfer their understandings of play into practices and what factors affect reflecting play in teaching.

In contrast to Norwegian participants, Turkish mothers thought that play was a way of spending time and energy. This implies that play is a context for keeping them occupied and using up energy, which coincides with previous research findings (McInnes \& Birdsey, 2015). As the researchers stated (e.g. Eberle, 2014; Gray, 2013; Smith \& Pellegrini, 2013; Smith \& Vollstedt, 1985), play exists for its own sake. Children do not have any other special reason to play. The process, in other words, playing in itself is more valuable than its end, for children. The Turkish children's definition of play as an action, "play is to play," seems to coincide with this way of conceptualizing play.

One aspect of Norwegian mothers and teachers' idea of the object of play focused on the player by perceiving play as a way of deciding by themselves. This is a unique object of play, which is to approach play from the "player" perspective rather than "thing to play" perspective.

With respect to the mothers and teachers' alternatives to play, both Turkish and Norwegian participants mentioned that they could not imagine play not existing. An interesting finding from this study was that the 'Turkish mothers' considered technology as an alternative to play. This implies that they treated technology related play as not being play. Similarly, in the study by Rothlein and Brett (1987), when children were asked what they did when they were not playing, most of them said they watched television. This finding also coincides with what Howard et al. (2002) suggest about the act of play and playfulness. Children may demonstrate the act of play when they engage in using technological devices, but they may not feel playfulness. Nevertheless, it has been found that the responses of Turkish mothers to technology vary in this study. While some of the participant mothers saw the technology as an alternative to the play and some mothers expressed that their children could play with technological devices, some of them said that they do not allow their children to play with these tools.

Norwegian adults stated that there would be school and homework if there is no play. This finding is striking when the features of early childhood education programs in both countries are taken into account. Play is the essential part of the curriculums in these two countries (Turkish Ministry of National Education 2013 Preschool Education Program and Norwegian National Program). Thus, the schools are supposed to be joyful places where children play and become happy. Likewise, there is no homework during preschool year both in Turkey and in Norway. It is possible 
that Norwegian mothers, teachers, and Turkish children might have thought about older children and posterior school experiences that they observed.

Findings related to the participants' play material choices revealed the preferred tools of play activity in each culture. While most of Turkish participants preferred Lego blocks that children can play with, Norwegian parents considered fixed play equipment, and teachers mentioned dramatic play materials as the most preferred tools of play. With respect to the reasons for preferred play materials, the children across countries stated positive feelings like having fun.

In terms of what children cannot play and reasons for it, the participants' responses from two cultures were quite different. Turkish participants gave several reasons for why children "cannot play outside," such as parents' lack of time to take children to natural areas or playgrounds, and their fear of children getting sick or injured. Turkish literature showed that outdoor play opportunities for children have declined recently because adults are anxious about and overprotective of their children in relation to playing outdoors (e.g. Cevher-Kalburan, 2014; Erbay \& Saltal1, 2012; Cevher-Kalburan \& Yurt, 2011). In this juncture, a thorough investigation of Turkish adults' thoughts about children's outdoor play seems to be crucial in supporting efforts to benefit from outdoor play opportunities. Having limited access was a reason stated by Turkish children, mothers, and Norwegian teachers.

The findings related to what children can and cannot play revealed specific information about the rules and the division of labor components of CHAT. The responses regarding the question about the reasons for the play materials that children can play across all the participants overwhelmingly focused on the feelings of having fun, being happy, not getting bored, and liking. Then, the rule here in determining with what to play with and where to play relates to feelings. The reasons for the play materials that children cannot play with were related to adult issues such as their concerns for children's health and limited access to certain play materials. At this point, the division of labor seems to center around adults' decisions as to what is appropriate for children. The exception to this situation was the Norwegian mothers and teachers' perception of children as decision makers for their own play. The object for these participants, which was discussed above, was to allow children to make their own decisions, consistent with their responses about what children can play and cannot play. This object coincides with both the rules and the division of labor components. This way of perceiving play reflects the approach that children own play, not the adults around them. The consistency between the object and the rules may provide children with opportunities to interact with materials and people based on their own choices. Research has shown that mothers 
with higher education level value children's play more and give their children more freedom of play (e.g. Fogle \& Mendez, 2006; İvrendi \& Işıkoğlu, 2008; Bringolf-Isler, Grize, Mäder, Ruch et. al, 2009; Lin \& Li, 2018). In our study, the education level of the Turkish mothers was mostly under the high school, while the Norwegian mothers' bachelor's degree and above.

Another future study investigating the relationship between children's way of conceptualizing play and their real play experiences could be conducted. As a limitation of this study, participants were interviewed only in order to reveal their understandings of play. Therefore, using multiple methods, such as observations and in-depth interviews could provide more comprehensive insight into this issue. Additionally, conducting interviews by using visual materials such as videos, photographs, or story-based interviews with children could ensure the collection of more detailed data including factors that may affect their understanding of play such as children's play opportunities like places, playmates, and materials.

Despite with these limitations, this study is still unique in that it showed children, mothers, and teachers' similar and differing thoughts about play both in Turkey and in Norway. The similarities and the differences regarding the understanding of play emerging in these two different cultures provide further evidences about how children and adults from different cultures perceive play. Shedding light on such understandings is essential since they reveal cultural features that impede or facilitate child play.

It is recommended that adults who take care of or work with children can be supported in using children's perceptions of play as a basis for providing appropriate environments and time for children to play freely. Also, they can act playfully and be involved in play, not to control but for getting a better understanding of the children's play world. From this point of view, recognizing the importance of play and a having a clear understanding of it is essential for giving children endless opportunities to play.

\section{REFERENCES}

Badzis, M. (2003). Teachers' and parents' understanding of the concept of play in child development and education. (PhD dissertation), University of Warwick.

Blackwell, C. K., Lauricella, A. R. \& Wartella, E. (2014). Factors influencing digital technology use in early childhood education. Computers \& Education, 77, 82-90. doi: http://dx.doi.org/10.1016/j.compedu.2014.04.013.

Bratterud, A., Sandseter, E. B. H. \& Seland, M. (2012). Barns trivsel og medvirkning i barnehagen. Barn foreldre og ansattes perspektiver. Retrieved from 
https://www.udir.no/globalassets/upload/barnehage/forskning og statistikk/rapporter Lbarns-trivsel-og-medvirkning-i-barnehagen.pdf, date of access April 20th, 2018.

Bringolf-Isler, B., Grize, L., Mäder, U., Ruch, N., Sennhauser, F. H., \& Braun-Fahrländer, C. (2009). Assessment of intensity, prevalence and duration of everyday activities in Swiss school children: A cross-sectional analysis of accelerometer and diary data. The International Journal of Behavioral Nutrition and Physical Activity, 6(50), 1-10. doi:10.1186/1479-5868-6-50

Cevher-Kalburan, N. (2014). Young children's opportunities and parent's opinions regarding outdoor play. Journal of Studies on Social Policy, 32, 113-135.

Cevher-Kalburan, N. \& Yurt, Ö. (2011). School playgrounds as learning environments: Early childhood teachers' beliefs and practices. Paper presented at the 7th International Conference on Education, INEAG, Samos, Greece, July 7-9.

Creswell, J. (1998). Qualitative inquiry and research design: Choosing among five traditions. Sage Publications: California.

Eberle, S. G. (2014). The elements of play: Toward a philosophy and a definition of play. American Journal of Play 6(2), 214-233.

Einarsdottir, J. (2014). Children's perspectives on play. In The Handbook of play and learning in early childhood, edited by Liz Brooker, Mindy Blaise, and Susan Edwards, 319-329. UK: SAGE Publications

Erbay, F. \& Saltal1, N. (2012). The Place of play in six-year-olds' daily life and mothers' play perception. Kerşehir Journal of Education Faculty 13(2), 249-264.

Erdoğan, S., Haktanır, G., Köksal, A. \& Çakır, A. (2004). The Place which $i$ wish to play an analises of six years old children's drawings: Turkey sample. Paper presented at OMEP World Council and Conference, Kuşadas1, October 5-11.

Fogle, L. M., \& Mendez, J. L. (2006). Assessing the play beliefs of African American mothers with preschool children. Early Childhood Research Quarterly, 21(4), 507-518.

Foot, K. A. (2014). Cultural-Historical Activity Theory: Exploring a theory to inform practice and research. Journal of Human Behavior in the Social Environment 243: 329-347. doi: 10.1080/10911359.2013.831011.

Frost, J., Wortham, S., \& Reifel, S. (2001). Play and child development. Upper Saddle River, NJ: Merrill/Prentice-Hall.

Göncü, A. and Gaskins, S. (Eds.) (2007). Play and development: Evolutionary, sociocultural and functional perspectives. Mahwah, NJ: Erlbaum Press.

Göncü, A., Mistry, J., Mosier, C. (2000). Cultural variations in the play of toddlers. International Journal of Behavioral Development 24(3), 321-329.

Graue, E. M., \& Walsh, D. J. (1998). Studying children in context: Theories, methods and ethics. Thousand Oaks, California: Sage. 
Gray, P. (2013). Free to learn: Why unleashing the instinct to play will make our children happier, more selfreliant, and better students for life. New York: Basic Books.

Grbich, C. (2013). Qualitative data analysis: An introduction (2nd ed.). London: Sage.

Greig, A., Taylor, J., \& MacKay, T. (2007). Doing research with children (2 ed.). London: Sage.

Howard, J. (2002). Eliciting young children's perceptions of play, work and learning using the activity apperception story procedure. Early Child Development and Care 172(5), 489-502.

Howard, J., Bellin, W., \& Rees, V. (2002). Eliciting children's perceptions of play and exploiting playfulness to maximise learning in the early years classroom. BERA Annual Conference 2002 Paper presentation.

Işıkoğlu, N. \& Ivrendi, A. (2008). Mothers and fathers' participation in play. Pamukkale University Journal of Education 24, 47-57.

Ivrendi, Asiye, and Nesrin Işıkoğlu. (2010). A Turkish view on fathers' involvement in children's play. Early Childhood Education Journal 37(6), 519-526. doi: 10.1007/s10643-010-0376-2

Johnson, J., Christie, J. \& Wardle, F. (2005). Play development and early education. USA: Pearson Education Inc.

Karrby, G. (1989). Children's conceptions of their own play. International Journal of Early Childhood Education 21(2), 49-54. doi: 10.1080/0300443900580110.

Koçyiğit S. \& Baydilek, N. (2015). Analysis of the preschool children's perceptions about play. YYU Journal of Education Faculty 12(1), 1-28.

Küçükali A. (2015). Children's rights to play and the changing play culture. Erzincan Üniversitesi Sosyal Bilimler Enstitüsü Dergisi (ERZSOSDE) 8(1), 1-14.

Lin, X. Y., \& Li, H. (2018). Parents' play beliefs and engagement in young children's play at home. European Early Childhood Education Research Journal 26(2),161-176. DOI:10.1080/1350293X.2018.1441979.

McCurdy, L. E., Winterbottom, K. E., Mehta, S. S., \& Roberts, J. R. (2010). Using nature and outdoor activity to improve children's health. Current Problems in Pediatric and Adolescent Health Care 40(5), 102-117.

McInnes, K. \& Birdsey, N. (2015). Understanding play: The perceptions of children, adolescents, parents and teachers. In L.A. Barnett (Ed). Play of individuals and societies (pp.105-116). Oxford: Interdisciplinary Press

McInnes , K., Howard , J., Miles, G., \& Crowley, K. (2011). Differences in practitioners' understanding of play and how this influences pedagogy and children's perceptions of play. Early Years: An International Research Journal 31(2), 121-133.

McPake, J. \& Plowman, L. (2010). At home with the future: Influences on young children's early experiences with digital technologies. In N. Yelland (ed.), Contemporary Perspectives on Early Childhood Education (pp.210-226). McGraw Hill: Open University Press. 
Miller, E. \& Kuhaneck, H. (2008). Children's perceptions of play experiences and the development of play preferences: A qualitative study. American Journal of Occupational Therapy 62(4), 407415.

Morris, L. B. (2013). Mother's perceptions of their children's play: Scale development and validation. Universal Journal of Psychology, 1(3), 121-144. doi: 10.13189/ujp.2013.010306.

Moser, T. \& Martinsen, M. (2010.) The outdoor environment in Norwegian kindergartens as pedagogical space for toddlers' play learning and development. European Early Childhood Education Research Journal, 18(4), 457-471. doi: 10.1080/1350293x.2010.525931.

NMER. (2017). Framework plan for the kindergartens. Oslo: Norwegian Ministry of Education and Research.

Nussbaumer, D. (2012). An overview of Cultural Historical Activity Theory use in classroom research 2000 to 2009. Educational Review 64(1), 37-55. doi: 10.1080/00131911.2011.553947

Oers, B.V. (2013). Is It Play? Towards a reconceptualisation of role play from an Activity Theory perspective. European Early Childhood Education Research Journal 21(2), 185-198. doi: 10.1080/1350293X.2013.789199.

Oksal, A. (2005). Perception of play in Turkish culture. Paideia: Cadernos de Psicologia e Educacao 15(30), 69-77. doi: 10.1590/S0103-863X2005000100009.

Özdemir, A. A., \& Ramazan, O. (2014). Preschool teachers' opinions about play. Journal of Research in Education and Teaching, 3(4), 298-308.

Patton, M. Q. (2015). Qualitative research \& evaluation methods (4th ed.). Thousand Oaks, California: Sage Publications.

Pyle, A. \& Alaca, B. (2018). Kindergarten children's perspectives on play and learning. Early Child Development and Care 188(8): 1063-1075. doi: 10.1080/03004430.2016.1245190.

Ramazan, O., Özdemir, A.A., \& Beceren, B. O. (2012). Evaluation of play from private and public prepoint of view. Procedia - Social and Behavioral Sciences 46, 2852-2856.doi: 10.1016/j.sbspro.2012.05.576.

Rothlein, L., \& Brett, A. (1987). Children's, teachers; and parents' perceptions of play. Early Childhood Research Quarterly 2(1). 45-53. doi: 10.1016/0885-2006(87)90012-3.

Samuelsson, I. P. \& Carlsson, M. A. (2008). The playing learning child: Towards a pedagogy of early childhood. Scandinavian Journal of Educational Research 52(6), 623-641. doi: 10.1080/00313830802497265.

Sandseter E. B. H. (2012). Children's participation and well-being in outdoor activities in Norwegian early childhood centres. Paper presented at the The 22nd EECERA Conference Pre-birth to Three: Idenities Learning Diversities, Oporto Portugal, August 28 - September 1.

Shiakou, M. \& Belsky, J. (2013) Exploring parent attitudes toward children's play and learning in cyprus. Journal of Research in Childhood Education 27(1), 17-30. doi: 10.1080/02568543.2012.739592. 
Smith, P. K. (2010). Children and play. Wiley Blackwell.

Smith, P. K. \& Pellegrini, A. (2013). Learning through play. In Encyclopedia on Early Childhood Development, edited by Peter K. Smith, 1-6. http://www.childencyclopedia.com/play/according-experts/learning-through-play.

Smith, P. \& Vollstedt, R. (1985). On defining play: An empirical study of the relationship between play and various play criteria. Child Development 56(4), 1042-1050.

Statistics Norway. (2017). Kindergartens 2016 final figures. Retrieved from https://www.ssb.no/en/utdanning/statistikker/barnehager/aar-endelige/2017-03-21 , date of access March 12th, 2018)

Sundberg, B., Areljung, S., Due, K., Ekström, K., Cottander, C., \& Tellgren, B. (2016) Understanding preschool emergent science in a cultural historical context through Activity Theory, European Early Childhood Education Research Journal 24(4), 567-580. doi: 10.1080/1350293X.2014.978557.

Tekin, G. \& Tekin, A. K. (2007). Meanings of child's play according to Turkish early childhood educators: A phenomenological study. Journal of Instructional Psychology 34(4), 207-213.

Temur, Ö. D. \& İnan, H. Z. (2010). Women as a mother and her play relation with the child. The Journal of International Social Research Volume 3(13), 86-95.

Tuğrul, B. (2017). Dünya oyunun gücünde uzlaştı şimdi bu gücü çocukların yararına kullanma zamanı: Hadi Türkiye...Erken Cocukluk Çalssmalar Dergisi 1(2), 259-266.

Turkish Ministry of National Education. (2013). Preschool Education Program. Ankara: MEB.

Turkish National Education Statistics. (2017). (accessed November 1, 2017). http://www.tuik.gov.tr/PreHaberBultenleri.do?id=24645

Van Manen, M. (1997). Researching lived experience. Human science for an action sensitive pedagogy (2nd ed.). London, Ontario: Althouse Press.

Vickerius, M. \& Sandberg, A. (2oo6). The significance of play and the environment around play. Early Child Development and Care 176(2), 207-217. doi: 10.1080/0300443042000319430.

Whitebread, D.,Basilio, M. \&Verma, M. (2012). The importance of play: A report on the value of children'splaywith a series of policy recommendations. Toy Industries of Europe (TIE).

Whitebread, D., Coltman, P. Jameson, H. \& Lander, R. (2009). Play, cognition and self-regulation: What exactly are children learning when they learn through play? Educational \& Child Psychology 26(2), 40-52.

Wing, L. A. (1995). Play is not the work of the child: Young children's perceptions of work and play. Early Childhood Research Quarterly 10(2), 223-247.

Yamagata-Lynch, L.C. (2010). Activity systems analysis methods: Understanding complex learning environments, USA: Springer. 
Yelland, N. (2011). Reconceptualising play and learning in the lives of young children, Australasian Journal of Early Childhood 36(2), 4-12.

\section{Appendix 1}

The interview questions posed to the participants in a systematic manner were:

(1) What is play?

(2) What comes to your mind when you hear the word "play"?

(3) What is it like to play?

(4) If there was no play, what would take its place? 